\title{
Potential of halal industry areas to improve national economic growth
}

\author{
N. Muyassaroh* \& F. Slamet \\ Universitas Negeri Malang, Malang, Indonesia \\ M. Sakti \\ UPN Veteran Jakarta, Jakarta, Indonesia
}

\begin{abstract}
Industrial Revolution Era 4.0 is a new era of industrialization, where Indonesia can further maximize the potential of Natural Resources (NR) and Human Resources (HR) owned. The halal industry is one of the most promising industries in the global market. The large Muslim population in Indonesia is a driving factor that creates great opportunities for the halal industry's growth to improve the national economy. In addition, Indonesia has successfully raised its ranking in the world halal market, ranging from the food sector, Islamic finance, cosmetics, medicines to halal tourism. This shows that Indonesia has great potential to be a major producer and player in the world halal market. Therefore, to realize this target, Indonesia needs to establish a halal industrial area. The concept of a halal industrial area is formed from an existing area. However, with adequate facilities and systems to produce halal products following the Halal Product Guarantee (HPG). The development of this area is intended so that the impact and benefits of the existence of the halal industry can be managed to the maximum with one management group so that it will be more efficient in its operations. Th e urgency of the halal industry area is to maximize the potential of the halal industry as well as the opportunity to become a major producer in the global halal market so as to increase national economy.
\end{abstract}

Keywords: halal industry, national economic growth, halal revolution

\section{INTRODUCTION}

Industry 4.0 has served as a new round of industrialization that had a big impact on various sectors in Indonesia. Industrialization has transformed Indonesia from an agricultural country into an industrial country contaminated with digitalization. This is evidenced by the government's determination to target Indonesia to become a resilient industrial country by 2035 . This determination is motivated by the abundant potential of Indonesia's Natural Resources (NR) and Human Resources (Kemenperin 2017). Not only that, Indonesia's commitment to becoming an Industrial country was even seen before the monetary crisis in 1997-1998. Indonesia was once named as a candidate for an Asian Tiger because of the significant changes in economic structure from an agricultural country to an industry. This is marked using the manufacturing industry as the driving force of national economic progress (Yusof 2011).

Based on data from the Ministry of Industry (2017), non-oil and gas industry growth in the third quarter of 2017 reached 5.49 percent. Non-oil and gas industry branches reached the highest percentage, including the metal industry by 10.60 percent, food and beverage 9.46 percent, and machinery and equipment reached 6.35 percent. However, along with the development of industry in the world, Indonesia has increased in industry in general and in the halal industry. The halal industry market in Indonesia, especially the food, travel, fashion, medicine and halal cosmetics sectors have reached 11 percent in the global market in 2016 (Annisa 2019). The percentage

\footnotetext{
${ }^{*}$ Corresponding author
} 
continues to increase to raise Indonesia's ranking in the Global Islamic Economy Index (GIEI), including Indonesia being ranked first in the Muslim Food category, ranked third in the Muslim Apparel category, ranked fifth in the Muslim Travel category, and ranked sixth in the halal region category (Hakim 2019). These achievements show that Indonesia has great potential to develop the halal industry sector (Annisa 2019). In addition to being influenced by the large Muslim population in Indonesia, this potential is also driven by a global phenomenon that makes the halal market a new growth sector in the global economy, even becoming the most promising sector in Asia, the Middle East, Europe and America. The market for halal-certified food and products is currently growing, both domestically and internationally (Elasrag 2016).

Indonesia is the country with the largest Muslim population. But it is unfortunate that as a country with the largest Muslim population globally, Indonesia is only a destination for halal products from abroad and has not been an important player in the industry as a whole. The government through the National Planning and Development Agency, has inaugurated and launched the Indonesian Sharia Economy Masterplan (MEKSI) 2019-2024. In addition, the National Committee on Islamic Finance (KNKS) was also established to implement MEKSI 2019-2024 into national development and building a halal industry in Indonesia because the development of the Islamic financial economy is not currently in line with expectations. In supporting Sharia economic development through the halal industry, Indonesia is expected to be able to maximize local wisdom in capturing global market opportunities.

The Halal Industrial Estates' existence become very important to facilitate in terms of supervision and monitoring, considering that Indonesia has now become a country that has increased its ranking in the halal industry sector. As the purpose of building a halal industrial area is intended so that the impact and benefits of the existence of the halal industry can be managed to the maximum in one management to be more efficient in its operations (Alrasyid 2016). The development of a Halal Industrial Estates also has the potential to encourage in creased investment in the halal industry sector, provide legal certainty regulate the management of industrial estates (Syahruddin 2010), and increase the demand for goods and services in a region to advance the economy of the community (Istiqomah \& Prasetyani 2013). Anchored by this background, this research was designed to explore the potential of halal industrial areas to improve national economic growth.

\section{LITERATURE REVIEW}

Special Economic Zones are areas that have the advantage to maximize industrial activities, exports, imports, and other economic activities that have high economic value. The development of SEZ in Indonesia began with establishing the Free Trade Area and Free Port (FTAFP) or the commonly called Free Trade Zone (FTZ) in 1970. Furthermore, Indonesia designed a Bonded Warehouse Zone in 1972. The next development was followed by the establishment of industrial estates in 1989, Integrated Economic Development Zones (IEDP) in 1996, and most importantly, the Special Economic Zone (SEZ) in 2009 (Suryani \& Febriani 2019). As per Law No.39 of 2009, the establishment of KEK aims to accelerate regional development and act as a breakthrough model for regional development for economic growth, including industry, tourism, and trade so as to create jobs (Suheri \& Aulia 2017).

One form of SEZ development is the development of industrial estates. This development has also been regulated in Presidential Decree No. 41 of 1996, which was taken to encourage industrial development through industrial sites' construction in the form of industrial estates (Sagala et al. 2004). UNIDO (2012) differentiates the development goals of industrial estates in developed and developing countries. In developed countries it aims to minimize negative externalities (such as pollution and congestion), so that industrial estates are planned as warehousing clusters and distribution centers. In some countries, industrial estates are converted into eco-industrial parks, while in developing countries, industrial estates aim to (1) encourage economic growth and employment at the national, regional and local levels; (2) attract foreign investment; and (3) spur the development of the industrial sector. 
The approach to SEZ development must be dynamic in order to improve competitiveness between regions globally. SEZ needs to be oriented towards the competition of science and technology to produce innovations that are the specialty of a SEZ in Indonesia (Suheri \& Aulia 2017). A great potential of KEK in Indonesia is the development of Halal Industrial Estates because of the potential of the Indonesian halal industry in the global market today.

\section{METHODS}

This research used a qualitative method with a literature study approach. A qualitative approach is a process of research and understanding based on a methodology that investigates social phenomena and human problems. In this approach, researchers created a complex picture, examined words, detailed reports from respondents' views, and conducted studies on natural situations (Sugiyono 2005). The literature study method included a reassessment of related literature covering systematic descriptions, critical analysis, and the evaluation of relevant texts. The data used for the study of this literature comes from secondary data that includes data released by institutions, papers and journals (Muhyiddin et al. 2017).

\section{DISCUSSION}

\subsection{Potential development of halal industry in the global market}

The global halal market has emerged as a new growth sector in the global economy. The halal industry's growth continues to increase in many parts of the world, and the industry is set to become a competitive force in world international trade (Elasrag 2016). This can be proven by achieving the global halal industry estimated to be worth around 2.3 trillion USD (excluding Islamic finance). Growing at an estimated annual rate of $20 \%$, the industry is worth about 560 billion USD per year. This rapid growth is influenced by the size of the world's Muslim population, which is expected to reach 1.8 billion soon. However, with the times, Halal is no longer just a religious obligation for Muslims, but also a strong market force and the market phenomenon around the world for both Muslims and non-Muslims (Azmi et al. 2013).

Many halal industry consumers are increasing the halal market demand, which refers to the needs and desires arising from customer and community pressures (Tieman 2007; Kamaruddin \& Jusoff 2009). The halal industry has seen considerable growth and development over the years, driven by increased awareness of halal products among consumers and product manufacturers (Global Leader 2008). Therefore, the halal industry is now expanding ou tside the food sector, which includes pharmaceuticals, cosmetics, health products, toiletries, and medical devices, as well as components of the service sector such as logistics, marketing, print and electronic media, packaging, branding, and financing (Azmi et al. 2013).

The growth of the halal industry can be seen from the contribution of several halal industry sectors to the world economy. Based on data from The State of the Global Islamic Economy Report 2015-2016, the size and profile of the global Muslim consumer market spending on food and beverages amounts to $\$ 1.128$ billion ( $17 \%$ of global expenditure). Comparatively, this was a $4.3 \%$ increase in Muslim food \& beverage spending of $\$ 1.081$ billion. Muslim food spending is expected to grow to a market of $\$ 1.585$ billion by 2020 and will account for $16.9 \%$ of global expenditure. This equates to a 2014-20 CAGR growth of 5.8\% (Elasrag 2016).

In addition to the food and beverage sector, pharmaceutical and health products are also a major growth area in the global halal industry. Demand for pharmaceutical products, generic drugs, health, and halal care are estimated to reach around 555 billion USD in Muslim-majority countries. The growth of the halal medicines markets globally increased by $4 \%$ in 2009 to a value exceeding 820 billion USD (Elasrag 2016). Furthermore, in the halal cosmetics sector, the market's growth is reflected by the development of consumer knowledge about the ingredients used, and product 
awareness, which is driven by social networks. The global halal cosmetics industry is estimated to reach 13 billion USD, with an annual growth rate of $12 \%$. Currently, the halal cosmetics market constitutes $11 \%$ of the total global halal industry (Elasrag 2016).

Rapid growth also occurred in the halal tourism sector. The halal tourism market represented $12.3 \%$ or 126.1 billion USD of the total global outgoing tourism market and grew by $4.8 \%$ compared to the global average of 3.8\%. In 2011 alone, Muslim tourists spent around USD126 billion USD. This figure is expected to reach 419 billion USD by 2020. The MENA market represents the largest share of the world's Muslim tourist expenditure by 60\%. (Azmi et al. 2013). Based on this phenomenon, it is not surprising that the halal industry trend continues to rise from year to year. Compound Annual Growth Rate (CAGR) projects the halal industry will increase to reach $6.2 \%$ in 2018 to 2024 (Fathoni et al. 2020). Of course, this becomes a global market that can continue to be developed in Indonesia.

\subsection{Opportunities for Indonesia to become a major producer of halal industry}

In today's increasingly globalized world, Islamic economies continue to grow and require companies to provide products and services that meet their faith-based needs (Nisha \& Iqbal 2017). According to the Global Economic Report, the Sharia economy in Indonesia was ranked 10th in 20182019 (Sharia 2019). The ranking is not comparable to Indonesia's Muslim population, reaching 12.6 percent of the total world season population. This figure is equivalent to $87.2 \%$ of the total Indonesian population (912 million people) (Hakim 2019). This potential makes Indonesia the largest consumer of the halal industry in the world. This statement is supported by data from the Global Islamic Economy Report (GIER). In 2019-2020, Indonesia's halal food consumption reached 173 billion US dollars (Yurivito 2019). In fact, this phenomenon can be an opportunity for Indonesia to become the largest halal industry producer in the world. This opportunity can be realized by maximizing the potential of the leading sectors of the halal industry in Indonesia, including halal food, halal tourism, Muslim fashion, integrated agricultural creative industries, and renewable energy (Sulaiman 2019).

The halal industry's huge potential can be seen from the development of several sectors in Indonesia, such as the food and beverage sector can contribute up to 3.3 billion USD from Indonesia's exports to Islamic Cooperation Organization (ICO) countries and non-OIC countries in 2017. The next sector that has a big potential is Muslim fashion. This can be seen from the Ministry of Industry data that about 30 percent of small, micro, and medium enterprise (MSMEs) industry players are engaged in Muslim fashion (Yolanda 2019). These sectors have great potential to be exported to boost the productivity of the halal industry in Indonesia.

\subsection{Role of halal industrial estates in boosting national economic growth}

The halal industry does have a strategic role in improving the national economy. This potential can already be seen from the data of the Ministry of Finance of the Republic of Indonesia in 2019 which states that the halal industry has contributed 3.8 billion USD to Gross Domestic Product (GDP) and 1 billion USD of investment from foreign investors, as well as opening 127 thousand jobs per year. In fact, if this potential is optimized again, the halal industry can increase the value of exports and foreign exchange reserves of the country. In addition, the halal industry also always shows a positive trend every year. This can be seen through the contribution of the Sharia economy to Gross Domestic Product (GDP) of 3.8 billion USD annually. Besides, the halal industry also has the potential value of Indonesia's exports, which is one of the driving factors of economic growth. The value of exports that can be produced from the halal industry ranges from 5.1 billion USD to 11 billion USD annually. In 2018, the halal industry generated 7.6 billion USD (Fathoni et al. 2020).

The halal industry's huge potential encourages the government to immediately create a new strategy to achieve these opportunities by establishing a halal industrial area. This area's concept is formed from existing industrial estates, but with adequate facilities and systems to produce halal 
products following the Halal Product Guarantee (HPG). The initiation of the establishment of the Halal Industrial Estate is a form of Indonesia's efforts in pursuing the progress of other countries in terms of the halal product industry (Yurivito 2019).

The Ministry of Industry, together with stakeholders, seeks to accelerate the growth of Sharia economy from regional aspects, namely encouraging the preparation of the halal industry ecosystem with the issuance of the Regulation of the Minister of Industry No. 17 of 2020 on Procedures for Obtaining Certificates in the Framework of The Establishment of Halal Industrial Estates. The regulation is a guide for industrial estate managers in improving infrastructure facilities and infrastructure supporting halal industry activities and guiding the halal industry in creating halal industry manufacturing, centralized and located in the halal industrial area.

Indonesia officially has the first Halal Industrial Area, the modern Halal Valley in Cikande, Banten. The Director of Sharia Economic Development and Halal Industry of the National Committee for Islamic Economics and Finance (KNEKS) said this was a concrete step to realize the great strategy of the Islamic Economic Development plan of Indonesia. The establishment of the Halal Industrial Estate must go through the conformity verification process established by the Ministry of Industry and the Halal Product Assurance Regulatory Agency (HPARA) and the Indonesian Ulama Council (MUI). In addition, it is also thanks to the encouragement given by KNEKS, which consists of the Ministry of Industry, Ministry of Religious Affairs, and other stakeholders.

The presence of this Halal Industrial Area will encourage the development of the halal products industry in Indonesia to be more advanced. Including producing more and more halal products of good quality for the domestic consumption market and to serve the needs of the world halal products. In addition, the development of the Halal Industrial Estate is also the first step to improve Indonesia's current position as a consumer country of halal products. As we advance, Indonesia can become the world's leading producer of halal products with an integrated halal area.

This shows that the halal industry market has contributed significantly to the development of the global economy. Nowadays, the use of halal products is motivated by religious demands or the large population of Muslims in the world and the growing awareness that halal products are quality products and guarantee consumer safety.

\section{CONCLUSION}

Indonesia has considerable opportunities and the potential for the development of the halal industry. If this potential is maximized, it will contribute to national economic growth. Optimization of the halal industry in Indonesia can be implemented through the development of Halal Industrial Estates. This region exists to create a new climate in the development of industrialization in Indonesia from capitalist to Sharia-based. This transition is a very appropriate step, considering Indonesia has an Islamic State background with the world's largest Muslim population. Indonesia is also ranked 10th in the world in terms of the application of the Sharia economy. These backgrounds have made Indonesia gain high confidence in developing the halal industry in the global halal market. Optimization of industrial estate development creates an increase both in national and global economy.

\section{REFERENCES}

Alrasyid, M. H. 2016. Environmental Strategic Management for Green Industrial Area. IJEEM - Indonesian Journal of Environmental Education and Management, 1(1), 101-116.

Annisa, A. A. 2019. Kopontren and the Halal Value Chain Ecosystem. Scientific Journal of Islamic Economics, 5(01), 1. https://doi.org/10.29040/jiei.v5i01.398

Anwar Fathoni, M., Hadi Syahputri, T., Economics and Business, F., \& National Development Veteran Jakarta, U. 2020. Portrait of Indonesia's Halal Industry: Opportunities and Challenges. Scientific Journal of Islamic Economics, 6(03), 428-435. 
Elasrag, H. 2016. Halal Industry: Key Challenges and Opportunities. SSRN Electronic Journal, 69631. https://doi.org/10.2139/ssrn.2735417.

Dar, H., et al. 2013. Global Islamic Finance Report: GIFR 2013, Edbiz Consulting.

Global Leader. 2008. World Population Prospects the Islamic Bombs. Retrieved November 17th, 2009, from http://www.freeworldacademy.com/globalleader/population.htm.

Hakim, R. 2019. The urgency of halal Special Economic Zone (KEK). Archives of Scientific Publications Bureau of Academic Administration.

Istiqomah, N., \& Prasetyani, D. 2013. Analysis of the impact of the existence of industrial estates in the village needs to increase economic activity of the community in mojosongo subdistrict boyolali district. Journaling \& Proceeding FEB Unsoed, 3(1), 1-11.

Kamaruddin, R. and Jusoff, K. 2009. An ARDL Approach in Food and Beverages Industry Growth Process in Malaysia. International Business Research, vol.2 no. 3 pp.98-107.

Ministry of Industry. 2017. Reached 5.49 Percent, Industrial Growth Skyrocketed Above the Economy.

Ministry of Finance of the Republic of Indonesia. 2019. "Financial Media." Ministry of Finance 14(140). Majlis, F. H. 2011. The Market Opportunity of the Muslim World.

Muhyiddin, N. T., Tarmidzi, I.M., Yulianita, A. 2017. Economic \& Social Research Methodology. Jakarta: Publisher Salemba Empat

Nisha, N., \& Iqbal, M. 2017. Halal ecosystem: Prospect for growth in Bangladesh. International Journal of Business and Society, 18(S1), 205-222.

Othman, P., Sungkar, I. and Sabri Wan Hussin, W. 2009. Malaysia as an International Halal Food Hub: Competitiveness and Potential of Meat-based Industries. Asean Economic Bulletin, vol.26no.3, pp. 306-320.

Othman, R., Ahmad, Z.A. and Zailani, S. 2009. The effect of institutional pressures in the Malaysian halal food industry. International Business Management, vol.3, no.4, pp. 80-84.

Sagala, Aryanto, et al. 2004. Preparation of Industrial Estate Development Plan. Jakarta: BPPT Press.

Sari, A. N. 2018. Implementation of supervision of The Center for Drug and Food Control and Institute of Food, Medicine, and Cosmetics Assessment of Majelis Ulama Indonesia as an effort to protect consumers on cosmetic products in Serang City.

Suheri, T., \& Aulia, S. S. 2017. Triple Helix Analysis in a Special Economic Zone (Case Study: Sei Mangkei KEK). Proceedings of the National Seminar on Engineering, Computer and Engineering, v51-v58. http://prosiding-saintiks.ftik.unikom.ac.id/jurnal/analisis-triple-helix-dalam.46

Sugiyono, I'm sorry. 2005. Administrative Research Method. Bandung: Alfabeta Sulaiman, Dawn. 2019. Indonesia Has a Chance to Become a Halal Industry Producer. (https://www.wartaekonomi.co.id/read255374/ indonesia-punya-peluang-jadi-produsen-industri-halal). Retrieved October 6, 2020.

Suryani, N. I., \& Febriani, R. E. 2019. Special Economic Zone and Regional Economic Development: A Literature Study. Convergence: The Journal of Economic Development, 1(1), 40-54.

Syahruddin. (2010). Evaluation of Implementation of Industrial Estate Development Policy. Journal of Administrative and Organizational Sciences, 17(1), 31-42.

Tieman, M. 2007. Modern Cluster Applications for Age-Old Halal. The Halal Journal, pp. 45-48.

Yolanda, Friska. 2019. Great Potential of Indonesian Halal Industry.

Yurivito, Benedictus. 2019. Indonesia Is a Major Player in the World Halal Industry.

Yusof, R. 2011. Development of National Industry and The Role of Foreign Investment (PMA)-Rohalia.

Yusof. EKonomi And Education, 71-87. 